\title{
HYDROGEN PRODUCTION ANALYSIS: PROSPECTS FOR UKRAINE
}

Nataliia Kovalenko ${ }^{\mathrm{a}}$, Taras Hutsol ${ }^{\mathrm{b}}$, Vitalii Kovalenko ${ }^{\mathrm{c}^{*}}$, Szymon Glowacki ${ }^{\mathrm{d}}$, Sergii Kokovikhine, Viktor Dubik ${ }^{\mathrm{b}}$, Oleksander Mudragel ${ }^{\mathrm{f}}$, Maciej Kuboń ${ }^{\mathrm{g}}$, Wioletta Tomaszewska-Góreckag

${ }^{a}$ Faculty of Agrarian Management, Department of Administrative Management and Foreign Economic Activity, National University of Life and Environmental Sciences of Ukraine, Kyiv, Ukraine, e-mail: n.kovalenko@it.nubip.edu.ua, ORCID: 0000-0003-0621-8214

${ }^{\mathrm{b}}$ Institute of Energy, State Agrarian and Engineering University in Podilya, Kamianets-Podilskyi, Ukraine, e-mail: pro-gp@pdatu.edu.ua, ORCID: 0000-0002-9086-3672

c Agrobiological Faculty, Department of Fodder Production, Reclamation and Meteorology, National University of Life and Environmental Sciences of Ukraine, Kyiv, Ukraine, e-mail: kovalenko_v@nubip.edu.ua, ORCID: 0000-0001-7158-825X

${ }^{\mathrm{d}}$ Institute of Mechanical Engineering, Warsaw University of Life Sciences - SGGW, Warsaw, Poland. ORCID: 0000-0002-0373-6633

e Institute of Irrigated Agriculture of NAAS, Kherson, Ukraine, e-mail: serg.ac@ukr.net, ORCID: 0000-0002-1687-6889

f OSMUD Group, Executive Director, CEO, United Arab Emirates, e-mail: oleksander_mudragel@gmail.com

g Eastern European State College of Higher Education in Przemyśl, Książąt Lubomirskich 6, 37-700 Przemyśl, Poland, e-mail: m.kubon@pwsw.eu; w.tomaszewska-gorecka@pwsw.eu

*Corresponding author: e-mail: kovalenko_v@nubip.edu.ua

\begin{tabular}{l}
\hline ARTICLE INFO \\
\hline Article history: \\
Received: May 2021 \\
Received in the revised form: \\
June 2021 \\
Accepted: June 2021 \\
\hline Keywords: \\
biohydrogen, \\
ecology, \\
bioenergy, \\
sustainable development
\end{tabular}

\section{ABSTRACT}

Over the last few years, hydrogen energy has shifted from a little-studied field to the main one with which leading western countries associate the prospects of their national economies. The reasons are the unprecedented pace of development of hydrogen technologies. It turned out that they are able to provide significant reductions in greenhouse gas emissions, and thus bring closer the solution to the problem of global climate change. The first and foremost purpose of our investigation is to reveal that our country has ample opportunities to become the main supplier of hydrogen to the EU market, overtaking North Africa in the competition. Using the methods, authors studied the targets of the European funds towards development of energy production from biohydrogen, studied the potential for the implementation of hydrogen projects, possibilities of financing them and a potential ability of Ukraine to form internal and external markets for hydrogen energy. One of the main issues of Ukraine's possible participation in Europe's hydrogen energy program as a supplier and producer of renewable hydrogen is the possibility of its technically safe and cost-effective transportation to EU countries. As a conclusion to the authors' research, the path of the hydrogen industry development in Ukraine will help to receive additional investments in the Ukrainian economy for creation of new capacities for "green" hydrogen production. In return, Europe will receive research and evolution of the bioenergy component of the economy, which will permit the safe transition of Europeans to an affordable, competitive, and stable energy system. 
Nataliia Kovalenko et.al.

\section{Introduction}

It is a well-known fact that the world's reserves of conventional fuels are diminishing and the world's production of energy from alternative sources is constantly growing. Every year the number of countries that show interest in the development and use of renewable energy increases. The use of alternative energy sources has a global perspective for the further successful development of civilization. Around the world there are phenomena that disrupt stable civilized development of the society: depletion of traditional energy sources, increasing costs of their extraction, intensive pollution of the environment, destruction of the biosphere, generation of excessive amounts of organic waste of industrial, agricultural, and domestic origin. All these problems must be eliminated at an accelerated pace.

According to FAO's (The Food and Agriculture Organization of the United Nations) calculations, there are 10 million square kilometers of agricultural land on the globe, 40 million square kilometers are forested; deserts and semi-deserts cover about 49 million square kilometers. Every year, global photosynthesis produces about 220 billion tons of biomass (dry matter), of which $80 \%$ by forests, which is 170 billion tons. Two tons of biomass equals energetically to about one ton of oil. This means that the annual growth of forests is 25 times higher than the energy equivalent of annual oil production of 3.3 billion tons. In other words, biomass produced per 2 million square kilometers of forest under sustainable management could cover the annual global oil demand (Kuzmenko, 2015; Kovalenko et al., 2020).

The production of electricity from renewable sources reaches more than $30 \%$, namely 86,841 thousand tons of oil equivalent.

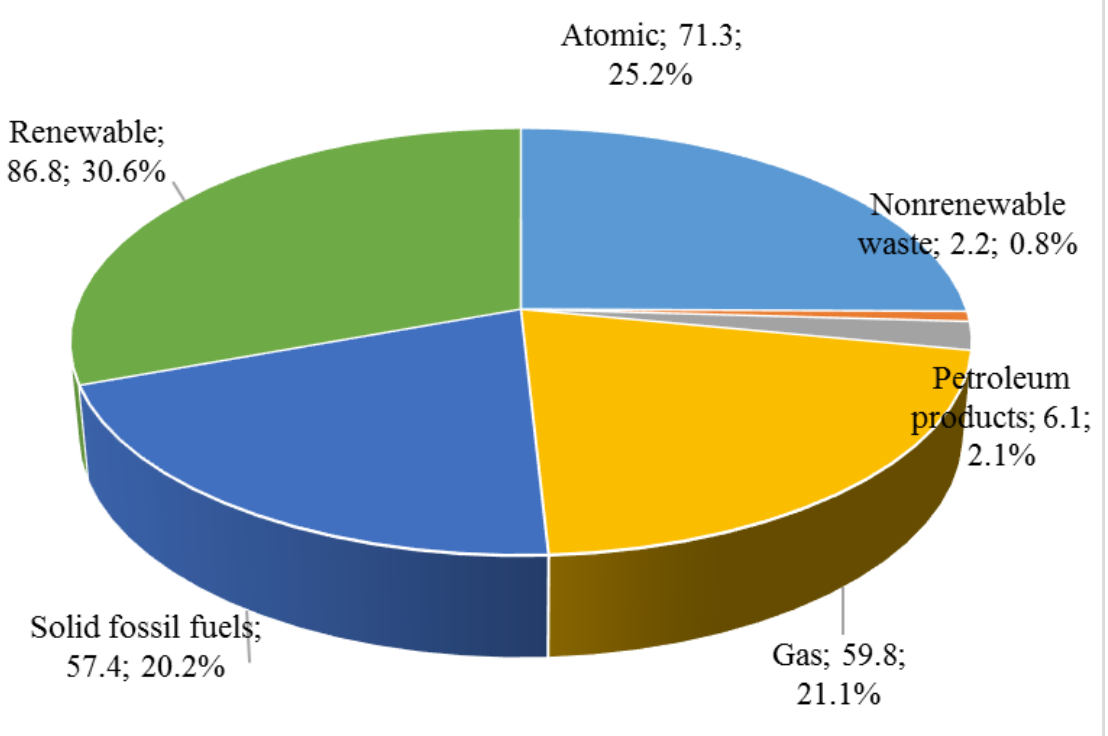

Figure 1. Gross electricity production by type of source in the EU-28 in 2017 (thousand tons oil equivalent). 
Hydrogen production analysis...

Biomass as a by-product or production waste (crop straw, sawdust, wood waste, biogas) is an alternative fuel that can replace traditional, expensive fossils in energy production. The fact that the specifics and personal potential of each EU country can be considered is also important for its use. .

The European Bioenergy Association has published a report on the development of the renewable electricity sector in Europe. A separate section of the report is devoted to the production of electricity from biomass and biofuels. The share of electricity from biomass in the gross electricity production in the EU-28 is 5.6\% (15,929 thousand tons oil equivalent), ranking 3rd among all RES after Hydro and Wind (Epshtein, 2020; Savchuk, 2020; Repkin, 2020).

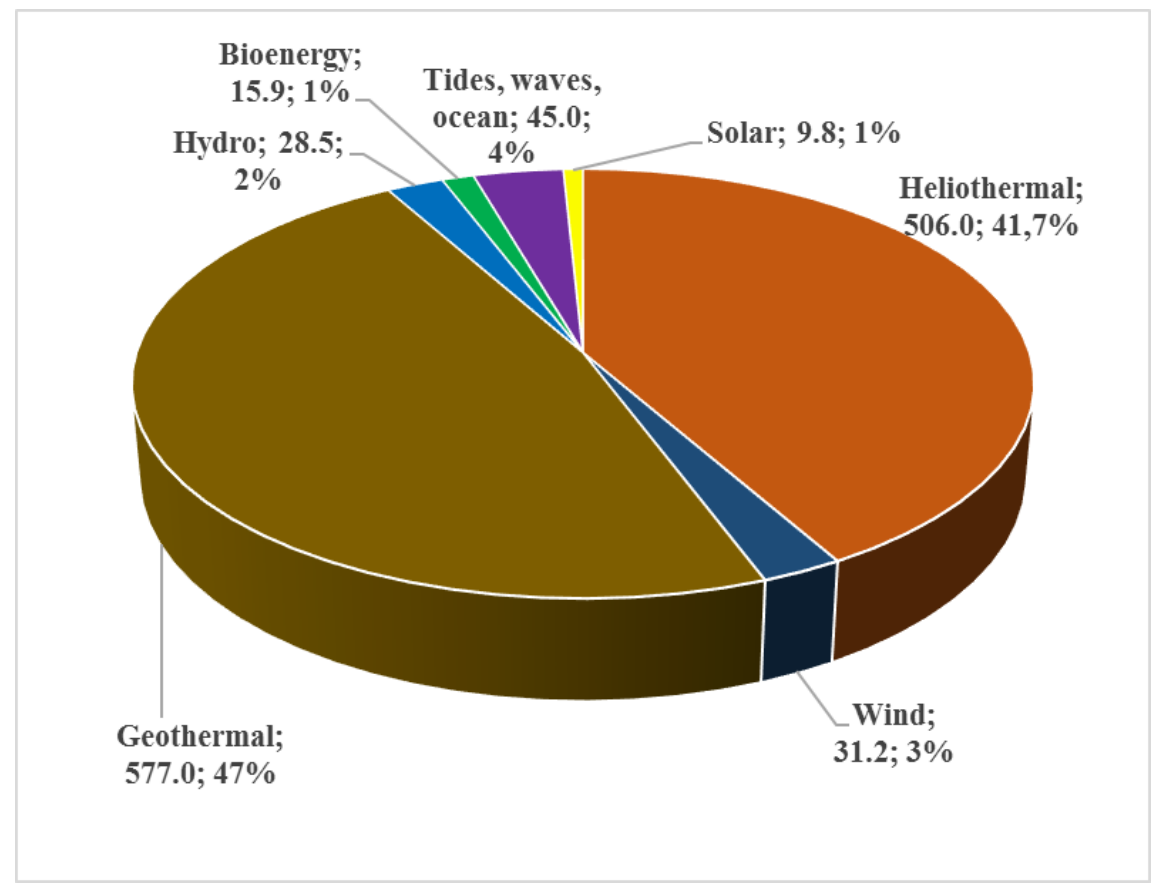

Figure 2. Electricity production from renewable energy sources in the EU-28 in 2017 (thousand tons oil equivalent).

Source: Sustainable Agribusiness Forum materials.

Bioenergy should be considered one of the most promising components of renewable energy in Ukraine (A European Green Deal, 2019). It is based on the use of biomass - carboncontaining organic substances of plant and animal origin - wood, straw, crop residues of agricultural production and so on. Biomass is a renewable, environmentally friendly fuel, the use of which does not increase the global greenhouse effect.

Today, the European Commission has two strategies in the field of energy - in particular, it provides for the introduction of clean and renewable energy carriers based on hydrogen 
Nataliia Kovalenko et.al.

technologies (EBA, 2020). This strategy covers 38 innovative areas of the entire EU energy system integration, which will significantly reduce the consumption of carbon energy carriers. At the same time, the European Commission offers a number of financial incentives to encourage industrial and residential consumers to use exactly renewable sources of clean energy. The hydrogen strategy envisages "decarbonization" of industry, transport, energy production and its domestic use. Europe is the world leader in hydrogen technology and is expected to use clean energy from wind and solar power plants to produce hydrogen energy carriers. In the subsequent period 2030-2050 hydrogen must become the EU's main energy resource and replace carbon carriers even in those sectors of the economy that are difficult to decarbonize (A European Green Deal, 2019).

The experience of the EU countries shows that there are many factors that influence the extent and prospects for the development and use of renewable energy sources. At the same time, the systems of economic incentives operating in these countries, which Ukraine lacks play a large role in this process (Tryhuba et al., 2021a; Kubon and Krasnodebski, 2010; Dziedzic et al., 2018).

- tax exemption of a part of the profit that is invested in the development of unconventional energy;

- compensation to tariffs for energy received from renewable energy sources

- exemption of consumers of "clean" energy from economic taxes; tenders and quotas ("green certificates") in support of various types of renewable energy sources from the general special fund.

An important component of any development program implemented in Ukraine should be its consideration in terms of sustainable development. The development of bioenergy issues is no exception. Sustainable development must become the organizing principle of all democratic societies, while supporting all other goals, policies, and processes. Thus, it provides a basis for integration of economic, social, and environmental issues over time, not just through trade itself, but by achieving and enhancing the public good. Sustainable development contributes to organization of good governance, healthy living conditions, innovation, lifelong learning, and all forms of economic growth that guarantee the preservation of natural capital, on which we depend (Kasprzak et al., 2018; Kayfeci et al., 2019; Nikolaidis and Poullikkas, 2017). This contributes to the improvement of social harmony and provides ways to protect the prospects of each individual to lead a full life.

The European Commission believes that thanks to the hydrogen technologies development, Ukraine is able not only to approach European standards, but also to become a significant international player in the energy market. They are ready to help us, but on condition that Ukraine also makes a lot of efforts (Ishaq and Dincer, 2021; Golub et al., 2020; Ni et al., 2006; Diachuk et al., 2017; Azizan et al., 2020).

Therefore, Ukraine as a state, as well as the Ukrainian producers, must fit into the environmental strategy of the European Union through actions and projects, and not just theoretical plans. Only in this case we will have access to funds within the framework of crossborder cooperation with the EU. They expect from Ukraine initiatives that will expand cooperation with the EU and will contribute to the decarbonization of the economy. This means that our country and business will have to pass the certification of production, the implementation of European climate standards and the transformation of the economy, the substitution of fossil fuels with renewable resources should be taken into account. If we express the potential of such a partnership as a percentage, then Brussels is ready to finance about $75 \%$ of 
Hydrogen production analysis...

all funds necessary for the integration of hydrogen technologies into the Ukrainian economy, and the remaining $25 \%$ are our domestic investments (Repkin, 2020).

In December 2019, the European Commission adopted the European Green Deal. The European Green Deal is a set of measures that determines the EU's policy for the coming years in such areas as climate, energy, biodiversity, industrial policy, trade. The main goal of this course is Europe's sustainable green transition to a climate-neutral continent by 2050 (A European Green Deal, 2019).

The European Green Deal is just being formed and is a dynamic instrument. Strategies, plans, legislation for the implementation of the European Green Deal in life will be developed and approved mainly during 2020-2021. Currently, the pace of implementation of the European Green Deal has slowed down slightly, despite the priority of responding to COVID-19. However, the European Commission emphasized that recovery should focus on a more resilient, greener, and digital Europe, solutions that not only benefit the economy but also the environment. This means that the Green Deal remains unchanged and that important components of the European Green Deal are on schedule. This approach was also supported by a number of EU member states, including Germany and France.

The Ukrainian government announced the intention of our state to join the European Green Deal. Such aspirations of the government are important, given the need to formulate policies in Ukraine in various fields that would consider environmental and climatic challenges (Bioenergy Association of Ukraine, 2020). At the same time, the full range of consequences of the European Green Deal for Ukraine should be taken into account in the context of the opportunities and threats that this creates for us. Formation of the main conclusions and recommendations regarding the impact of the European Green Deal is important at this stage, when Ukraine has not yet finally formulated its intentions, and the European Green Deal is also in the process of being formed and filled with content.

Ukraine as a Party to the Kyoto Protocol and the Paris Agreement has undertaken obligations, in particular, to take measures to limit greenhouse gas emissions and adapt to a climate change.

The draft concept of Ukraine's "green" energy transition by 2050, presented in January 2020 , is structurally and substantively the most similar document to the European Green Deal, taking into account the dynamism, intersectoral approach and ambition (the goal is climate-neutral economy by 2070).

Reducing the consumption of natural gas in the EU or replacing it with, say, "green" hydrogen (which is obviously a positive trend in the context of decarbonization) could leave Ukraine without transit revenues. This risk can be mitigated through the development of our own hydrogen energy, preventive adaptation to changes in the global natural gas market and the integration of the Ukrainian gas market into the EU market.

Hydrogen is a gas that can be obtained from water. It is the simplest and lightest of all chemical elements, which is an ideal fuel. When hydrogen is burned, water is formed, which can be decomposed again into hydrogen and oxygen, without any pollution of the environment. Carbon dioxide, carbon monoxide $(\mathrm{CO})$, hydrocarbons, soot, organic peroxides and others are not released during combustion (as when burning other types of fuel). Hydrogen has a very high thermal capacity: when burning $1 \mathrm{~g}$ of hydrogen, $120 \mathrm{~J}$ of thermal energy is released, and when burning $1 \mathrm{~g}$ of gasoline - only $47 \mathrm{~J}$ (Azizan et al., 2020). 
Hydrogen is a type of biofuel. The raw material used for its production is biomass. Given the current problems with the environment, the use of biohydrogen is completely environmentally friendly, because its combustion does not produce harmful substances.

In the present economy, hydrogen is used as a chemical rather than an energy raw material. It is used about 20 million tons per year: $50 \%$ goes to the production of ammonia and fertilizers, the rest - to remove sulfur from gaseous fuels in metallurgy, for the hydrogenation of coal and other fuels (International Energy Agency, 2018).

Currently, hydrogen is largely produced from fossil fuels, such as natural gas, and is therefore contaminated with $\mathrm{CO}_{2}$. Only the electrolysis of water with electricity from renewable sources creates green hydrogen - without $\mathrm{CO}_{2}$ emissions.

\section{Materials and Methods}

For analytical study on the prospects for the development of biohydrogen projects in Ukraine, the authors used materials from existing bioenergy foundations in Ukraine and $\mathrm{Eu}-$ rope. Among the domestic organizations are the Bioenergy Association of Ukraine (UAIBO) which includes the well-known Scientific and Technical Center "Biomass" and the public association "Agency for Renewable Energy", IRENA (International Renewable Energy Agency). The research and conclusions are based on the study of the objectives of the following programs and agreements: "European Green Deal" (A European Green Deal, 2019), "Green Hydrogen Investment and Support Report" (International Energy Agency, 2018), "FCH JU Hydrogen Roadmap Europe" (The Future of Hydrogen, 2020), "Green Hydrogen of Europe" (International Energy Agency, 2020). We have considered the goals of the European funds in the direction of the development of energy production from biohydrogen, studied the potential for the implementation of hydrogen projects, the possibilities of financing them and the potential ability of Ukraine to form internal and external markets for hydrogen energy.

The special research methods used in the work include: an abstract-logical method - in the study and research of the problem of bioenergy implementation and development; generalization - in assessing the current state of development and use of alternative energy sources from biomass; computational and constructive, graphical, proportional dependences of indicators - in the study and identification of dependencies between the studied indicators.

\section{Research results and discussion}

Ukraine is a country that heavily depends on imports of fossil fuels. Given the underdeveloped energy situation with its own natural resources, Ukraine faces the problem of reduction of natural gas consumption. The cost of natural gas is a great economic and political risk, which has caused problems in recent decades. As a result, a number of national economy sectors were on the verge of viability. In this regard, Ukraine must urgently look for alternative energy sources and implement energy-saving technologies. Widespread use of renewable energy technologies, especially biomass, can be one of the ways to reduce natural gas consumption (Kuzmenko, 2015).

Although, most of the electricity and heat in Ukraine is produced from traditional sources that pollute the environment, the situation should change in the coming years. Thus, Ukraine's 
Hydrogen production analysis...

commitments under the Protocol on Accession to the Energy Community (Gas Decarbonisation Pathways, 2020) include an action plan for the implementation of Directive 2009/28/EU on the promotion of the use of energy from renewable sources. We are talking about the adaptation of Ukrainian legislation in the field of renewable energy to EU legislation, in particular:

- development of technical requirements for the production and use of biofuels and bioliquids with reduction of greenhouse gas emissions;

- development of sustainability criteria for liquid and gaseous fuels produced from biomass, etc.

The development of bioenergy is very important for Ukraine as it has a significant potential of biomass, which is available for energy production. Biomass in Ukraine is enough to replace imports of gas, gasoline, and coal (about 23 million tons oil equivalent).

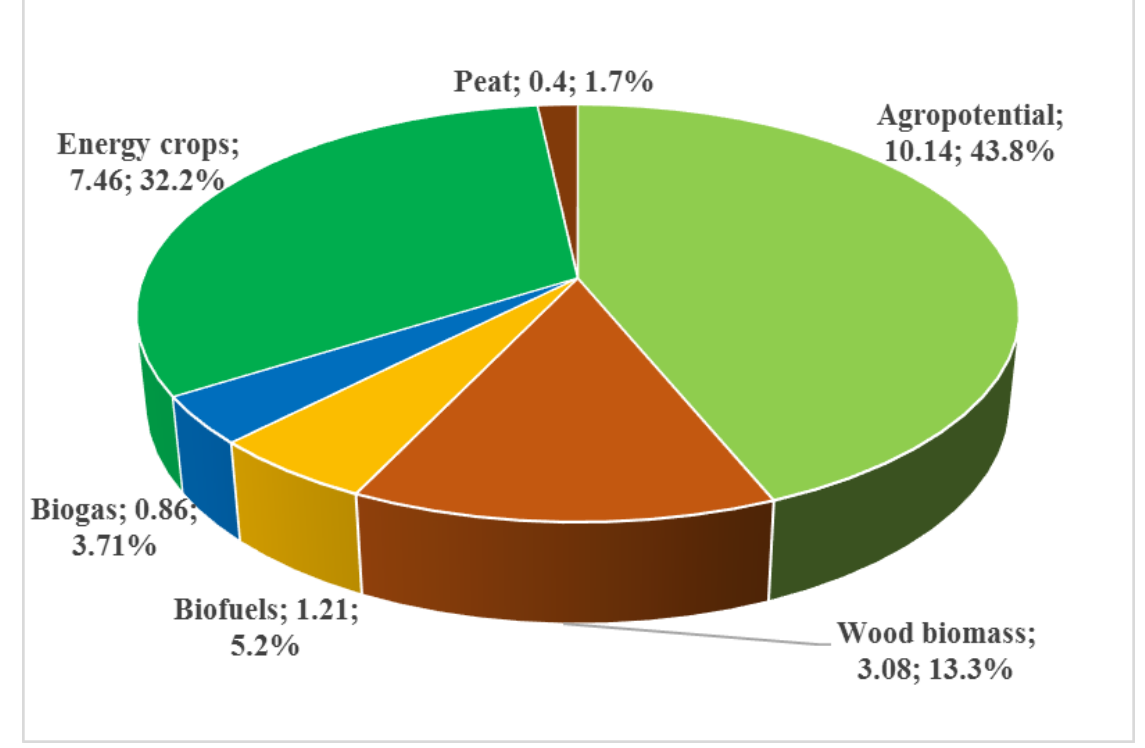

Figure 3. Bioenergy potential of Ukraine, 2018 (million tons oil equivalent).

Source: according to Bioenergy Association of Ukraine.

\section{Hydrogen as an energy raw material}

The European Renewable Energy Council has proposed introduction of the concept of "green or renewable" hydrogen as one of the renewable energy sources.

Proponents of the industrial use of green hydrogen believe that its use is a necessity for the development of the energy industry and the creation of a reliable and stable energy system of the future (Bioenergy Association of Ukraine, 2020). The European Council for Renewable Energy does not share such positions and points out that the large-scale introduction of renewable energy sources is a necessary condition for the use of hydrogen and its "promised" impact on the environment. Production of hydrogen in industrial conditions requires a com- 
plex multi-stage conversion process which requires both significant investment and significant electricity costs (Draft Roadmap for manufacture and use of hydrogen in Ukraine, 2021). First you need electricity, which would ideally be generated from renewable energy sources. Then it is necessary to ensure the electrolytic separation of the water molecule into oxygen and hydrogen atoms. Finally, for further transportation, the hydrogen is cooled, followed by liquefaction. This third stage is associated with the highest energy consumption. The last stage involves the direct production of heat or electricity from hydrogen in fuel cells. It should be emphasized that the compliance of each individual energy source with the criteria of economy, efficiency and environmental friendliness depends on the extent to which production technologies used in energy processing allow to avoid transport costs and electricity losses due to complex multi-stage conversion processes. Therefore, hydrogen is considered as a possible alternative for renewable energy, but in no case as a factor in the development of the latter.

Figure 4 shows a diagram of a standard reactor for hydrogen production in energy and chemical production.

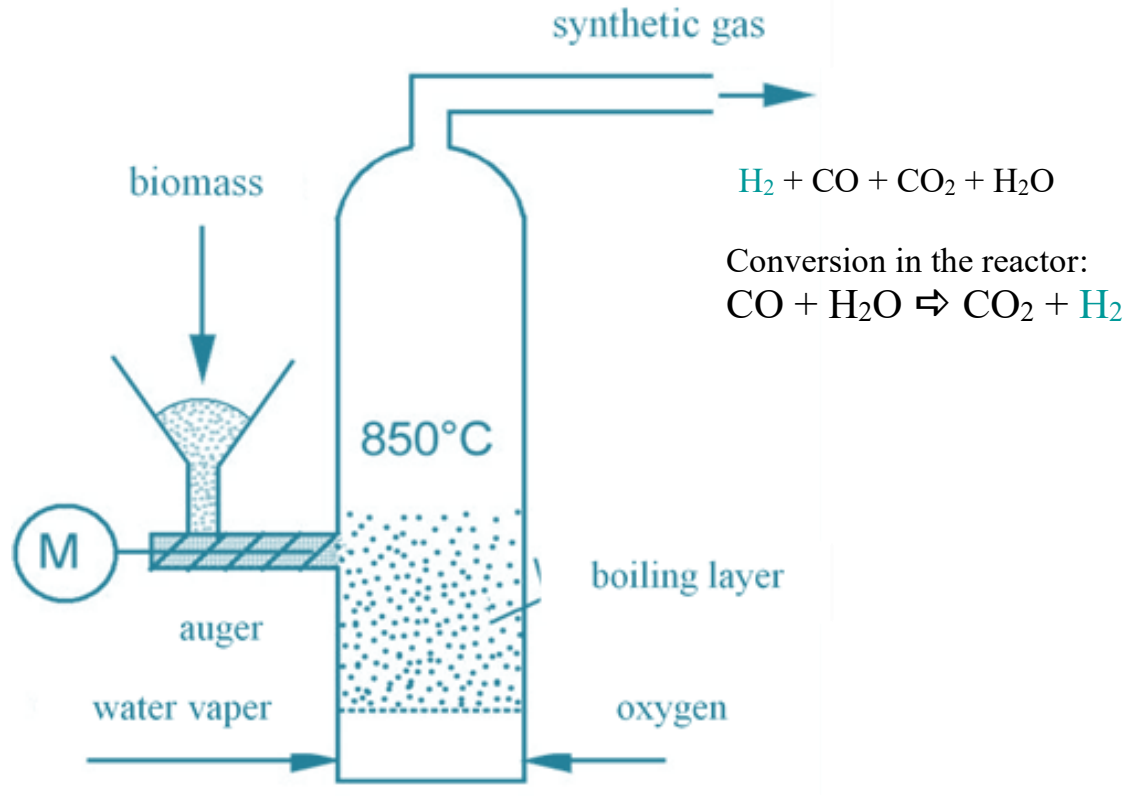

Figure 4. Hydrogen production in an industrial reactor

Source: according to Podhornyi (1998)

Chemical and electrochemical methods of obtaining H2 are uneconomical (Podhornyi, 1998). Biohydrogen is obtained:

- biochemically with biobutanol butyl or acetone-butyl fermentation of industrial plant biomass;

- by thermolysis of wood biomass; 
Hydrogen production analysis...

- by biogas reforming;

- by photolysis with algal biomass.

Biohydrogen is mainly produced by two main methods:

1. Thermochemical method - based on the fact that biomass is subjected to heat treatment at a temperature of $500-800^{\circ}$. Heating occurs in the absence of oxygen. The temperature of the process is below the temperature of coal gasification. As a result of this process, hydrogen and other gaseous products are released. It is planned to improve this process and, consequently, reduce the cost of production.

2. The biochemical method is the production of biohydrogen from biomass using special bacteria. If the biomass is rich in starch or it contains a significant amount of cellulose, it is advisable to use special enzymes that accelerate the process of biomass processing. Stable parameters (temperature $30^{\circ}$ and normal pressure) must be maintained for efficient process.

However, the developments of an ideal method of biohydrogen production does not stop. And production of this type of fuel from algae is gradually gaining popularity. This method is called photolysis. Since it has been found that algae produce biohydrogen under certain conditions, this process takes place in a special bioreactor. In the presence of a small amount of sulfur in the environment in algae, the process of photosynthesis is suspended, and then stops completely. In this case, the algae switch to the production of hydrogen instead of oxygen.

Another no less interesting way to obtain this fuel is to reform biogas. Reforming is well studied and widely used. The process of biohydrogen production by steam reforming is well established and is a good alternative in regions where there is a shortage of traditional fuels.

The table 1 shows the characteristics of the main technologies forproduction of hydrogen from biomass.

Table 1.

Characteristics of the main technologies of biohydrogen production.

\begin{tabular}{|c|c|c|c|}
\hline Characteristics & $\begin{array}{c}\text { Electrolysis } \\
\text { of water }\end{array}$ & $\begin{array}{c}\text { Plasma } \\
\text { gasification }\end{array}$ & $\begin{array}{l}\text { Steam } \\
\text { reforming }\end{array}$ \\
\hline Raw materials & biomass & solid household waste & biomass \\
\hline Technological process & $\begin{array}{l}\text { biochemical }+ \\
\text { electrochemical }\end{array}$ & thermochemical & $\begin{array}{l}\text { biochemical }+ \\
\text { thermochemical }\end{array}$ \\
\hline Stage of readiness & $\begin{array}{l}\text { industrial } \\
\text { production }\end{array}$ & $\begin{array}{l}\text { industrial } \\
\text { production }\end{array}$ & $\begin{array}{l}\text { industrial } \\
\text { production }\end{array}$ \\
\hline Temperature range, $\left({ }^{\circ} \mathrm{C}\right)$ & $50-800$ & $3500-5000$ & $700-1000$ \\
\hline The cost of production, $\left(\$ \cdot \mathrm{kg}^{-1}\right)$ & $4-5$ & $5-6$ & $2-3$ \\
\hline $\begin{array}{l}\text { Yield of hydrogen from } \\
1 \text { ton of raw material, }\left(\mathrm{m}^{3}\right)\end{array}$ & 120 & 500 & 300 \\
\hline Impact on ecology & + & + & + \\
\hline
\end{tabular}

Source: based on Epshtein (2020)

The analysis of the presented table showsthat the above methods of biohydrogen are quite expensive, have a quite high yield of hydrogen from 1 ton of raw material and are environmentally friendly. 
Nataliia Kovalenko et.al.

Today, the biochemical method of biohydrogen production is the most popular and widespread. Given that the raw materials may be agricultural waste (husks, meal, etc.), household organic waste, wastewater and sewage, the amount is inexhaustible. Furthermore, the production of hydrogen by this method does not require any special conditions and special equipment. Good bacteria are needed for efficient production. The most suitable for this work are purple bacteria, which are found in alpine springs. Bacteria can be reused after each production cycle. Therefore, this method depends entirely on the activity of bacteria, and it is less energy-intensive and cheaper.

In his papers, the scientist Podhornyi (1998) stressed the possibility of transportation and distribution of hydrogen and natural gas through pipelines. Advantages of this method include: pipelines are laid underground (does not disturb the landscape), occupy less land area (unlike power lines), and, compared with transmission of electrical energy in the form of alternating current, the advantage is given to the transmission of energy in the form of hydrogen gas through a pipeline. This is economically proven - transmission via a pipeline with a diameter of $750 \mathrm{~mm}$ over a distance of $80 \mathrm{~km}$ is cheaper than transmission of the same amount of energy in the form of alternating current by an underground cable. At a distance of more than $450 \mathrm{~km}$, hydrogen pipeline transportation is cheaper than the use $40 \mathrm{kV} \mathrm{DC}$ overhead power line, and at a distance of more than $900 \mathrm{~km}$, it is cheaper than $500 \mathrm{kV} \mathrm{AC}$ overhead power line. The author claims that when hydrogen becomes an available fuel, like natural gas today, it will completely and successfully replace it: it can be used in water heaters, heating stoves, kitchen stoves, etc. And since it does not emit harmful substances during combustion, there will be no need in a system for their removal for heating devices. In addition, the steam released during the combustion of hydrogen also moisturizes the air, which in apartments with central heating is too dry. And the absence of flues during construction (saving construction costs) increases the efficiency of heating by 30 percent.

The "green course" provides for the introduction of a carbon tax on imports in the EU that worries the Ukrainian exporters. The calculation method has not yet been precisely defined, but theoretically its size will depend on the amount of emission from the production of a particular product. The carbon tax on imports should level the playing field for the European and foreign producers. In theory, it should stimulate foreign companies to reduce $\mathrm{CO}_{2}$ emissions, without which the cost of their goods will additionally increase when crossing the European border. The Ukrainian producers will be able to avoid the new collection if they introduce climatic standards similar to the European ones.

\section{Transport}

Cars with hydrogen fuel cells are launched by Honda, Toyota, Hyundai, and a number of Chinese companies.

The only disadvantage of hydrogen cars is their cost. In hydrogen fuel cells platinum, a rare and expensive metal, is used - as a catalyst. Therefore, the cost of hydrogen cars starts from 70 thousand dollars (Hydrogen Europe, 2020).

In 2018, Germany launched the world's first train running on hydrogen fuel cells. The train can travel about $800 \mathrm{~km}$ at one gas station and carry 300 passengers (Hydrogen Europe, 2020).

Hydrogen transport faces many challenges: infrastructure, cheaper hydrogen and hydrogen transport, and security. 
Hydrogen production analysis...

Moreover, many experts emphasize that hydrogen is explosive. Hydrogen leakage cannot be traced, so there is a risk of formation of explosive mixtures.

Also, pure hydrogen cannot be transported by ordinary uncoated metal pipes, it makes the metal brittle, so the gas transmission system and consumer devices need to be upgraded.

Based on the above views, it can be argued that hydrogen is one of the most promising sources of renewable energy and Ukraine has broad prospects in this area of cooperation with the EU, where today there are serious intentions to develop cooperation with Ukraine in the spread of hydrogen technologies.

Ukraine's partnership as a major supplier of "green" hydrogen with the European Union, where hydrogen is gradually displacing fossil fuels and becoming a key energy resource, is a win-win strategy for both parties. Our country is able to become the main market for hydrogen production in Europe.

In order to successfully implement such intentions, which will strengthen Ukraine's European integration, a new structural unit for the introduction of hydrogen technologies is being created within the Ministry of Energy. A working group will also be set up with the involvement of experts from Ukraine and the European Union.

After the EU has made it a priority to replace coal generation, the gas sector has become an important part of achieving this goal. But the European Commission's ambitious plans to decarbonise the economy also mean the need to introduce green technologies in the gas sector to keep pace with the times and stay one step ahead of all market transformations that are important for tackling climate change.

One such innovative solution is the use of "green" (or "pure") hydrogen produced from water using electricity from renewable sources in gas supplies.

This technology (Power-to-Gas) involves the addition of "green" hydrogen to existing gas pipelines during the transportation of natural gas (up to $20 \%$ ). It is the most modern, simple, fast, and least expensive way to create a new hydrogen market, because it does not require investment in new infrastructure.

The addition of hydrogen to natural gas significantly improves its properties and reduces $\mathrm{CO}_{2}$ emissions during the operation of the gas transmission system. As a result, consumers have the opportunity to use not only safer and climate-neutral fuel, but also save on its purchase. After all, a mixture of natural gas and hydrogen gives more heat than ordinary natural gas, and therefore it is needed less, for example, for use in everyday life or industry (in metallurgical and chemical plants, in heat-generating boilers).

Ukraine has certain achievements in research on adding hydrogen to the gas transportation system. The first large-scale experiment began to be prepared by the Regional Gas Company (RGC) at the end of February 2019 (Draft Roadmap for manufacture and use hydrogen in Ukraine, 2021). The RGC for the first time in Ukraine began to test transportation of a mixture of hydrogen and natural gas in closed sections of the gas distribution system. This experiment is needed to understand how the existing gas delivery system will behave when using hydrogen. At first, it was planned to use a mixture of natural gas with hydrogen from cylinders in the networks in concentrations from $2 \%$ to $100 \%$. In the future it is lined up to build a hydrogen production unit.

It is noted that the case is a drop in the cost of electricity produced based on renewable energy sources (RES). For example, within the framework of "best-in-class" American RES projects, "green" hydrogen can be obtained even today at $\$ 1.53$ per kg, which makes it competitive with "blue" hydrogen which is obtained from fossil fuels (mainly natural gas) with 
$\mathrm{CO}_{2}$ capture, according to an analytical note by Morgan Stanley (Association "Energy Efficient Cities of Ukraine", 2021). The analytical note states that this would make green hydrogen produced by wind power competitive with new gray projects "much faster than previously thought", at a cost of about $\$ 1$ per $\mathrm{kg}$. Experts also note that the price of "green" $\mathrm{H}_{2}$ is "very sensitive" to the cost of electricity. Reducing it by $\$ 2$ per MWh reduces the cost of hydrogen by $0.10 \$ \cdot \mathrm{kg}^{-1}$.

According to the forecast of Bloomberg New Energy Finance (BNEF) "Prospects for the hydrogen economy", by 2050 , "green" hydrogen could meet up to $24 \%$ of global energy needs and reduce global greenhouse gas emissions from fossil fuels and industry by a third. And the price of "green" hydrogen will be equal to the cost of natural gas in energy equivalent in most regions of the world. However, such a scenario can only be realized if policies are implemented to scale up technology and reduce costs (Bloomberg New Energy Finance, 2021).

In 2020 we have the following situation with the assessment of the cost of hydrogen.

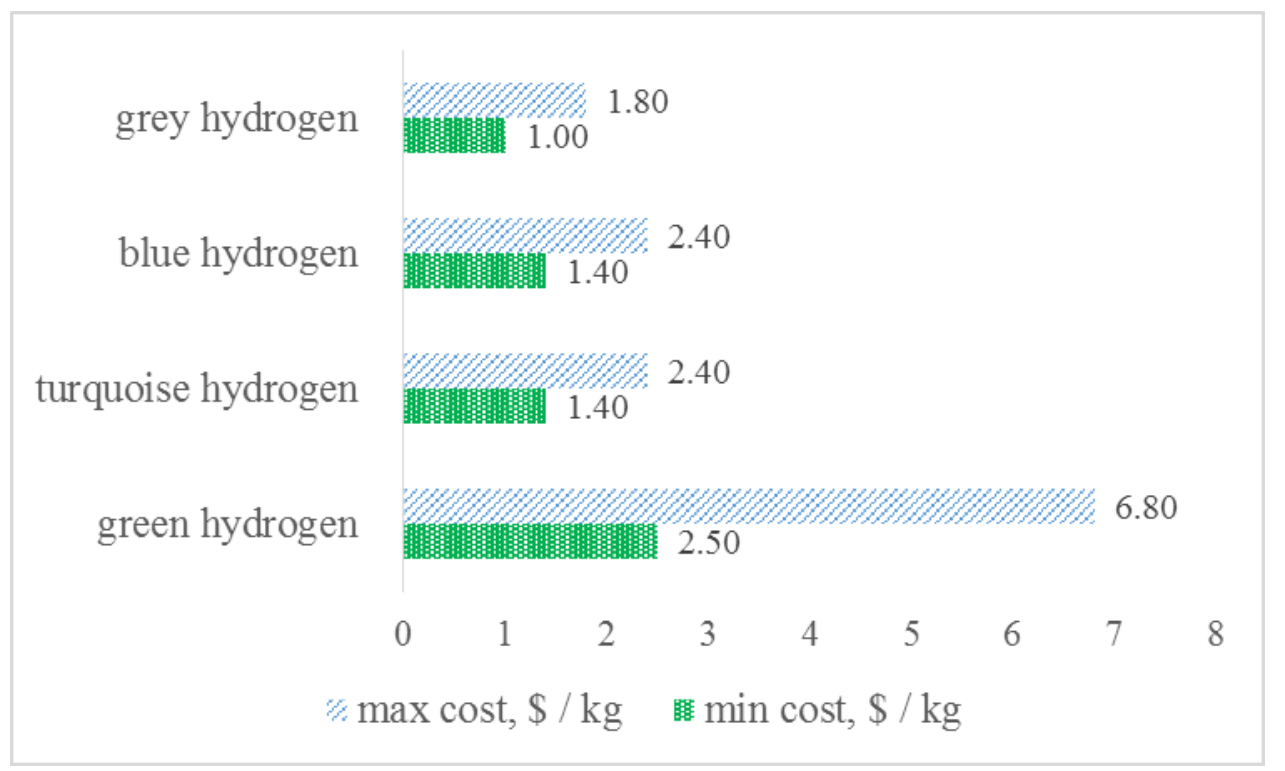

Figure 5. Cost of Hydrogen

Source: according to Association "Energy Efficient Cities of Ukraine” (2021).

As of 2020 green hydrogen costs between $\$ 2.50-6.80$ per kilogram and turquoise hydrogen 1.40-2.40 $\$ \cdot \mathrm{kg}^{-1}$ or blue hydrogen $1.40-2.40 \$ \cdot \mathrm{kg}^{-1}$ compared with high-carbon grey hydrogen at $1-1.80 \$ \cdot \mathrm{kg}^{-1}$ (Association "Energy Efficient Cities of Ukraine", 2021).

The bet on Ukraine as a priority partner made by the EU states to implement the Green Agreement on the introduction of the latest environmentally friendly technologies to reform 
Hydrogen production analysis...

key sectors of the European economy is well calculated. Ukrainian scientists have revolutionary scientific and technical developments in hydrogen technologies for generating electricity. They were highly appreciated in the world 20 years ago. Today the Europeans are ready to buy electricity at 18 eurocents per $\mathrm{kWh}$. However, according to the technologies of the Ukrainian researchers, it is about 23 eurocents, which is a more expensive indicator. According to economic and technological calculations (Association "Energy Efficient Cities of Ukraine", 2021), in 2023 the kilowatt-hour obtained from the system wind - electrolyzer transportation - fuel cell will cost 8 eurocents. This is already a business project that has the right to exist. Therefore, focusing on renewable energy and hydrogen, you can meet the needs of not only your own country, but also earn enormous amount of money for Ukraine.

Based on the research, it is established that the forecasted increase in the biohydrogen production projects, and the related technologies, will reduce the total biohydrogen production costs. Starting in $2030,80 \%$ of biohydrogen production from agricultural raw materials (Tryhuba et al., 2021b).

Now in Ukraine it is economically profitable to use "green" hydrogen. But due to climate change, the time is not far off when countries will pay much more for carbon emissions from fossil energy sources.

Projects in hydrogen energy in Ukraine are based on the demand for hydrogen consumption and research on the volume of its production until 2030 in Europe. The total volume of European investments until 2030 is estimated at 430 billion euros, and support for the development of this area is needed -145 billion euros. Thus, by 2030, the total investment in the hydrogen industry will amount to 575 billion euros (International Energy Agency, 2018).

The European Green New Deal provides Ukraine with an opportunity to quickly restore production of bioenergy potential and create and develop an industry that could potentially make Ukraine energy independent with an export-oriented economy.

\section{Conclusion}

1. Thus, hydrogen energy technologies have not yet gained the quality and efficiency in the world when they could replace traditional energy and existing oil technologies in transport. However, the potential of hydrogen technologies allows us to predict their widespread use in the future, which will contribute to these advantages of hydrogen over fossil fuels.

2. Hydrogen is gradually becoming one of the main directions that should contribute to achieving energy independence in Ukraine and the world. Governments have begun to create the conditions for investment in the development of hydrogen projects, which include finding ways to reduce the cost of production, technologies for use in various fields and building infrastructure. Thus, hydrogen has a new chance to become the main source of energy for the "green" future.

3. The development of the hydrogen industry in Ukraine will allow us to receive 20 billion euros of investment in the Ukrainian economy to create $10 \mathrm{GW}$ of new capacities for production of "green" hydrogen. It will also allow the formation of an internal market for hydrogen with various sources of the energy origin and creation of demand for this energy. Also, in the future, the possible use of the gas transmission system of Ukraine for the transportation of produced green hydrogen to European countries is being considered. 
4. In return, Europe will receive research and development of the bioenergy component of the economy, which will allow the safe transition of Europeans to an affordable, competitive, and stable energy system.

5. In future studies on the hydrogen energy development in Ukraine, we will consider the ecological and economic component of hydrogen domestic production. In the future, it is planned to consider the transport infrastructure in Ukraine, which is not yet ready to accept hydrogen cars, as is already practised in the world due to a high cost of fuel cells for cars. Also, one of the most interesting applications for hydrogen is heating residential buildings. Despite the high cost of hydrogen fuel, similar experiments are already being carried out in developed countries and we reflect on to calculate not only its environmental friendliness, but also its economic component.

\section{References}

A European Green Deal. Available online: https://ec.europa.eu/info/strategy/priorities-2019-2024/european-green-deal.

Association "Energy Efficient Cities of Ukraine". https://new.ingwb.com/doyourthing/sectors/are-weclose-to-the-hydrogen-tipping-point.

Mohammad, T.A.; Aqsha, A.; Mariam, A.; Ain, S.; Hellgardt, K.; Sumaiya, Z.A. and Farooq, S. (2020). Catalytic reforming of oxygenated hydrocarbons for the hydrogen production: an outlook. Biomass Conv. Bioref. 127, 109852.

Bioenergy Association of Ukraine. Available online: https:/uabio.org/bioenergy-transition-in-ukraine/. Bloomberg New Energy Finance (2021). Available online: https://about.bnef.com/

Diachuk, O.; Chepeliev, M.; Podolets, R.; Trypolska, G.; Venger, V., Saprykina, T. and Yukhymets, R. (2017). Transition of Ukraine to the Renewable Energy by 2050. Heinrich Boell Foundation Regional Office in Ukraine, Publishing house "Art Book" Ltd.,

Dziedzic, K.; Mudryk, K.; Hutsol, T. and Dziedzic, B. (2018). Impact of Grinding Coconut Shell and Agglomeration Pressure on Quality Parameters of Briquette, Engineering for Rural Development. Jelgava, 1, 1884-1889.

EBA. European Biogas Association. Available online: https://www.europeanbiogas.eu/2020-gas-decarbonisation-pathways-study.

Epshtein, Y. (2020). Vyrobnytstvo vodniu z biomasy. Available online: https://uabio.org/wp-content/uploads/2020/09/Epshtein_Green_hydrohen_29092020.pdf.

Gas Decarbonisation Pathways 2020-2050 - Gas for Climate. Available online: gasforclimate2050.eu.

Golub, G.; Skydan, O.; Kukharets, V.; Yarosh, Y.; Kukharets, S. (2020). The estimation of energetically self-sufficient agroecosystem's model. Journal of Central European Agriculture, 21(1), 168-175.

Hydrogen Europe. Available online: https://hydrogeneurope.eu.

Institute for Energy Economics and Financial Analysis. Available online: https://ieefa.org/morganstanley-green-hydrogen-could-be-economically-competitive-by-2023/.

International Energy Agency. Available online: https://www.iea.org/data-and-statistics/charts/currentpolicy-support-for-hydrogen-deployment-2018.

Ishaq, H. and Dincer, I. (2021). Comparative assessment of renewable energy-based hydrogen production methods. Renewable and Sustainable Energy Reviews, 135, 110192.

Kasprzak, K.; Wojtunik-Kulesza, K.; Oniszczuk, T.; Kuboń, M. and Oniszczuk, A. (2018). Secondary Metabolites, Dietary Fiber and Conjugated Fatty Acids as Functional Food Ingredients against Overweight and Obesity. Nat. Prod. Commun, 13, 1073-1082.

Kayfeci, M.; Keçebaş, A. and Bayat, M. (2019). Hydrogen production. Solar Hydrogen Production Processes. Systems and Technologies. Cambridge, Academic Press. 
Hydrogen production analysis...

Kovalenko, V.; Kovalenko, N.; Labenko, O.; Faichuk, O. and Faichuk, O. (2020). Bioenergy sustainable development: achieving the balance between social and economic aspects, E3S Web of Conferences, 154, 07008.

Kukharets, S.; Hutsol, T.; Glowacki, S.; Sukmaniuk, O.; Rozkosz, A. and Tkach, O. (2021). Concept of Biohydrogen Production by Agricultural Enterprises. Agricultural Engineering, 1, 63-72. https://doi.org/ 10.2478/agriceng-2021-0005

Kubon, M., Krasnodebski, A. (2010). Logistic cost in competitive strategies of enterprises, Agricultural Economics, 56, 397-402.

Kuzmenko, S. and Perederiy, N. (2015). Market of rapeseed: economic and bioenergetic perspective, Monograph, Komprynt.

National energy and climate plans (NECPs). Available online: https://ec.europa.eu/energy/topics/ energy-strategy/national-energy-climate-plans_en/

Ni, M.; Leung, D.Y.C.; Leung, M.K.H.; Sumathy, K. (2006). An overview of hydrogen production from biomass. Fuel Processing Technology, 87, 5, 461-472.

Nikolaidis, P. and Poullikkas, A. (2017). A comparative overview of hydrogen production processes, Renewable and Sustainable Energy Reviews, 67, 597-611.

Podhornyi, A. (1998). Vodorodnaia enerhetyka, Nauka.

Proekt Dorozhnoi karty dlia vyrobnytstva ta vykorystannia vodniu v Ukraini [Draft Roadmap for manufacture and use hydrogen in Ukraine] (2021). https://unece.org/sites/default/files/2021-03/Hydrogen\%20Roadmap\%20Draft\%20Report_UKR\%20March \%202021.pdf

Repkin, O. (2020). Plany YeS shchodo rozvytku vodnevoi haluzi do 2030 roku ta perspektyvy Ukrainy u tsii ekosystemi. Available online: https://ecolog-ua.com/news/plany-yes-shchodo-rozvytku-vodnevoyi-galuzi-do-2030-roku-ta-perspektyvy-ukrayiny-u-ciy.

Savchuk, S. (2020). Chomu Ukraina maie stymuliuvaty rozvytok vodniu. Available online: https://www.epravda.com.ua/projects/greendeal/2020/05/18/660480/.

Sustainable Agribusiness Forum. Available online: https://saf.org.ua/news/452/.

The Future of Hydrogen. Available online: https://www.iea.org/reports/the-future-of-hydrogen.

Tryhuba, A.; Hutsol, T.; Glowacki, S.; Tryhuba, I.; Tabor, S.; Kwasniewski, D.; Sorokin, D. and Yermakov, S. (2021a). Forecasting Quantitative Risk Indicators of Investors in Projects of Biohydrogen Production from Agricultural Raw Materials, Processes, 9(1), 258.

Tryhuba, A.; Hutsol, T.; Tryhuba, I.; Pokotylska, N.; Kovalenko, N.; Tabor, S. and Kwasniewski, D. (2021b). Risk Assessment of Investments in Projects of Production of Raw Materials for Bioethanol, Processes, 9(1), 12.

Tsina na voden vpade $\mathrm{v}$ try razy. Available online: https://glavcom.ua/new energy/news/cina-na-voden-vpade-v-tri-razi-698015.html.

Vodneva stratehiia YeS. Ukraina maie vykorystaty svii potentsial [EU hydrogen strategy. Ukraine must use its potential]. Available online: https://ukurier.gov.ua/uk/articles/vodneva-strategiya-yesukrayina-maye-vikoristati-s/

Zelenyi voden [Green hydrogen]. (2004). Zelena enerhetyka, 4, 16-17. 
Nataliia Kovalenko et.al.

\section{ANALIZA PRODUKCJI WODORU: PERSPEKTYWY DLA UKRAINY}

Streszczenie. W ostatnich latach energia pochodząca $\mathrm{z}$ wodoru z mało zbadanego obszaru stała się głównym tematem, w którym kraje zachodnie upatrują szansy dla swoich krajowych gospodarek. Wynika to z niesłychanego tempa rozwoju technologii wodorowych. Okazało się, że są one w stanie znacząco zredukować emisję gazów cieplarnianych i w ten sposób przybliżyć rozwiązanie problemu globalnej zmiany klimatu. Pierwszym i najważniejszym celem naszego badania jest wykazanie, że nasz kraj posiada duże możliwości, aby stać się głównym dostawcą wodoru na rynek europejski, wyprzedając w tym północną Afrykę. Przy zastosowaniu metod, autorzy dokonali przeglądu celów europejskich funduszy w kierunku rozwoju produkcji energii z biowodoru, możliwość wprowadzenia projektów wodorowych, możliwości finansowania potencjału Ukrainy do tworzenia wewnętrznych i zewnętrznych rynków energii wodorowej. Jednym z głównych kwestii możliwego udziału Ukrainy w europejskim programie energii wodorowej jako dostawcy i producenta odnawialnego wodoru jest możliwość jego bezpiecznego i opłacalnego transportu do krajów UE. Podsumowując, autorzy stwierdzili, że ścieżka rozwoju przemysłu wodorowego na Ukrainie pozwoli na uzyskanie dodatkowych inwestycji w gospodarce Ukrainy w celu stworzenia nowych możliwości produkcji zielonego wodoru. W zamian Europa otrzyma badania i rozwój nad wodorem, który jest elementem gospodarki. Co z kolei pozwoli na bezpieczne przejście Europejczyków na niedrogi, konkurencyjny i stały system energii.

Słowa kluczowe: biowodór, ekologia, bioenergia, zrównoważony rozwój 